\title{
Increasing Young Learners' Vocabulary Mastery By Using English Songs
}

\author{
Cicih Kurnia \\ English Education Department Faculty of \\ Teacher Training and Education \\ Mercu Buana University of Yogyakarta, Indonesia \\ email:chici_kurnia@yahoo.com
}

\begin{abstract}
Vocabulary is basic part of language when we learn english. Nowadays, introducing english vocabulary can be started in the kindergarten school. In early age, the young learners are easy to accept the language that has been given by teacher. Therefore, young learner in early age (approximately 3-4 years old) should get stimulation and learn english vocabulary in order to get preparation to study in higher level. This research was conducted to increase the young learners' vocabulary mastery in b class of tungga dewi day-care. The classroom action research was implemented in this research. The teaching technique using songs were implemented through teaching and learning activities in two cycles of classroom action research. Each cycle of classroom action research was planning, acting, observing and reflecting. In this research, instruments to gather the data were field notes and observation checklists. Field notes and observation checklists were applied to take the data during the teaching learning process. The data would be analysed in order to solve the problems. Songs were applied in the activities of the first cycle of classrooms action research. The result of the first cycle was not quiet successful because the average of post -test score in cycle one was 37,8. Therefore, the teacher-researcher conducted the second cycle. The second cycle was conducted based on the result of the first cycle. Songs were combined the body movement in second cycle of the classroom action research. The result of the second cycle was successful because the average of post-test score was 77,78. As a conclusion, it can be concluded that the implementation of english songs could help to increase the young learner's vocabulary mastery.
\end{abstract}

Keywords: young learner, vocabulary, songs, classroom action research

\section{Introduction}

Based on bill no. 20, 2003 especially in relation to article 1 about national education system for young learners in Indonesia or Pendidikan

Anak Usia Dini (PAUD), it states that young learners' education has been started from the day a child is born to the age of approximately six years old.
This system gives young learners early forms of education through stimulations obtained from their immediate environments. Young learners grow and develop their intelligences' to prepare them for the next educational stages through the stimulations. Young learners undergo several aspects of development including physical, cognitive, religious 
and moral value, socio-emotional and language.

In education, young learners acquire knowledge formally and informally. Informally, they absorb knowledge from their family and environment; whereas formally, they gain it from their school environment and teachers. As the source of knowledge, a teacher and a school institution must know about the learners' characteristics, stage of both mental, cognitive and language development aspect in order to teach appropriately and effectively.

Teaching young learners, however, is challenging for most teachers because it is so much different from teaching adults. Brown (2001:87) said that "to successfully teach young learners requires specific skills and intuitions that differ from those appropriate for adult teaching". Learning and teaching young learners is very different from adults because they easily get bored, easily forget and have attention span. Despite the challenges, however, young learners are highly potential language learners due to their stage of development called the critical period - a period where language is learned optimally.

Young learners can learn both first and even foreign languages, like English naturally or in other words they learn their first language in same way as they learn a foreign language. According to Wells (1986) young learners learn a language from what they hear what others are saying and imitate the intonation or accent of those around them. The young learners observe their surrounding and they will re-produce it many times more creatively. Nurfauziah (2013) says that "in the early age when young learners learn a foreign language, it is easier for them to understand the foreign language, too". Learning and introducing English as a foreign language to young learners, therefore, give more benefits rather than disadvantages.

English consists of some elements such as; expressions, vocabularies, pronunciation, and grammar or structure. Introducing vocabulary is important because it is one of the languages to be acquired if language speakers want to have really good skills in English. Vocabulary influences the mastery of four skills in English (Listening, Speaking, Reading, and Writing). The more vocabularies young learners have the better their mastery of English. In addition, a strong basic knowledge that the students have, can prepare them in learning English later on.

A teacher should not only know about her learners' characteristics and 
language development aspect, but also he or she must also be competent in using teaching media and be knowledgeable about young learners learning and acquisition processes. Teaching and learning media is useful for English teachers of. First, it attracts young leaners learning English. Second, it helps young learners to understand lessons better.

There are many forms of teaching-learning media, one of them is songs. Most young learners love to listen to and to sing songs, song is one way to improve young learners' vocabulary that can make easy to memorize. Consequently, teachers of young learners must be able to choose the right songs to teach related material. If the song is interesting, young learners will repeat the song so many times. The repetition indirectly helps them to memorize the word or expression. Of course, it is good for young learners to acquire vocabularies subconsciously.

Nowadays, the teacher of preschools or playgroups uses English songs in the class. English has been taught in a lot of preschools or playgroups because there are two positive perceptions regarding English learning at preschool and playgroup. The first comes from a psychologist named Tjokrosuprihatono (2010) which states that English stimulation or foreign language input can be given from early age. "The previous three years after children birth is good time or golden age to absorb all things or all stimulations", Tjokrosuprihatono continues. English should be taught from early age because the young learners in that age are easy to accept the input or stimulation that has been given by the teachers. It can help the teachers in introducing English itself to young learners.

The second perceptions from parents suggest that they have high ambition that their children can learn English lesson as soon as possible because they want their children can speak and master English language quickly. That is the reason why many parents send their children to go to the school which has an English subject. Brewster et al. (2002:1) states that "pressure to introduce early English learning has often come from parents". Brewster et al. (2002:1) "continues that parents have strongly beliefs that having English as a tool will benefit their children greatly by giving them more opportunities to gain economic, cultural or educational advantages". In short, it can help young learners to prepare for facing the global world. Parents also consider preparing their young learners to continue to study at higher level (kindergarten) where English is already taught. This is in line with Boen (1989) 
who says that young learners learn English "to prepare young learners linguistically, psychologically and culturally for language learning" (cited at Brewster et al., 2002:5)".

Since experts believe that English should be introduced to young learners early, the teacher-researcher conducted some self-observations. In the first observation, the teacher-researcher found problem while teaching and learning process in young learner class.

The teacher-researcher was observed in Tungga Dewi day-care Yogyakarta, the teacher did not introduce English vocabulary. They learnt Indonesian language in every meeting without inserted a few English vocabularies.

To get more data, the teacherresearcher asked the principle of Tungga Dewi day-care, she said that young learners did not learn English yet. Even in Tungga Dewi day care, there is no extracurricular English, but the school offers dance and music as extracurricular. She continued that young learners graduated from this school, and then they will continue to kindergarten. Almost of young learners will study in TK Negeri 1 Sleman or Masjid Kampus UGM kindergarten, because these schools cooperate with UGM and the location near UGM. Both of TK Negeri 1 Sleman and Masjid Kampus UGM kindergarten have an
English subject. This situation become problem when the young learners learn English in kindergarten. They have not the basic knowledge about English vocabulary. They have not a preparation yet.

Therefore, the teacherresearcher doing a research based on the problem raised. The teacher-researcher implements of the English songs to increase the students' vocabulary. The teacher-researcher focuses on vocabulary. When young learners' vocabularies get improvement, it will influence the other skill in language and it will give effect that young learners are confident. The researcher intended to solve that problem by conducting the classroom action research (CAR). This Classroom Action Research consists of plan, action, observation and reflection.

\section{Research Method}

In this research, the teacherresearcher applies CAR (Classroom Action Research) as a method. Based on Susilo et al., (2009:1) say that classroom action research is a teacher-researcher conducting a recycle investigation process in order to make improvement the system, process, and learning situation. Susilo et al., (2009:1) continues that CAR is a strategy to solve the problem through real action in detection and analysis the problem. The 
other expert, Kemmis and McTaggart describe that "action research is an approach to improving education by changing it and learning from the consequences of changes (cited at Prandika, 2013)". While the teacherresearcher employs action research, it gets good impact for learning activity. The learners get opportunity to increase their ability especially vocabulary in English.

There the characteristics of classroom action research (Susilo et al., 2009:5), are; a problem was conducted about teacher's matter in daily learning process in the class; some plans, implementations and methods of teaching to solve problem intended to revise and increase of learning quality in the class; there is a difference before and after implementing the classroom action research; and increasing quality of student learning outcome, learning process and teaching process in the class. According Lewin, the action research process consists of four steps; planning, acting, observing and reflecting (cited at Susilo et al., 2013:11).

Kemmis and Mc Taggart have same steps when the teacher-researcher conducted an action research, but the teacher-researcher conducts acting and observing step in same time. Kemmis and Mc Taggart (1992:10) state that "to do action research is to plan, act, observe and reflect more carefully, more systematically, and more rigorously than one usually does in everyday life (cited at Prandika, 2013).

There are two cycles implement in applying this study trough action research. The figure of action research cycle can be seen on below:

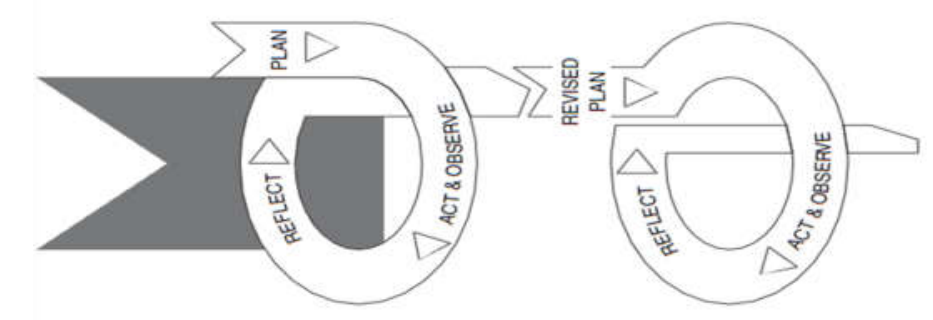

Figure 3.1 the action research spiral based on Kemmis and Mc Taggart

According to Kemmis and $\mathrm{Mc}$ Taggart's procedures in conducting classroom action research, those four stages would be implemented in this study. The first stage is planning; this term covers the problem identification. 
In this stage, the teacher-researcher finds the problem to conduct the study. This stage consisted of three steps which were (1) asking permission from the school's principal, (2) conducting preliminary study, and (3) making some plans. The first step in research procedures was asking permission from the school's principal. The teacherresearcher went to Tunggadewi DWP $U G M$ day-care to get permission to conduct this research. The teacherresearcher told to the school principals that the teacher-researcher wanted to conduct the research in Tunggadewi $D W P$ UGM day-care. The teacherresearcher delivered the purpose and the reason why the teacher-researcher want to conduct this study in her school.

The second step was preliminary study, this step aiming to know the real situation and condition in the class. The teacher-researcher observed during learning process to collect some information about the class condition and found problem during learning process. The finding the problem process was done by observing and interviewing before implementing this research. First the teacher-researcher observed during teaching and learning process to know the real situation in young learner class (B class) Tunggadewi DWP UGM day-care.
During observation, the teacherresearcher took a field note some conditions related to teaching and learning process in young learner class (B class).

Then, the teacher-researcher did interview with the teacher to get deep understanding about $\mathrm{B}$ class condition. Not only the teacher-researcher did interview with teacher of B class, but also the teacher-researcher also did interview with school's principal and young learners' parent who graduated from Tunggadewi DWP UGM day-care in order to get deeper information before starting this research.

Making some plans was the third step. Making some plans was a reflection from the result of preliminary study before conducting the research. In this case, the teacher-researcher did some activities, such as; making a lesson plan, preparing material, preparing song, making observation checklists, field notes, and making pre-test and post-test. The teacher-researcher made planning that using English song to introduce and increase young learners' vocabulary mastery. The teacher-researcher hoped that the young learners not only grabbed knowledge but also happiness in teaching and learning process. The teacher-researcher believed that it would improve the young learner vocabulary. 
The second stage is the combination of acting and observing.

The teacher-researcher conducts the second step and third step in same time.

The teacher-researcher acts out a lesson plan which is arranging in teaching and learning process. The teacher-researcher implements to young learners based on all education theories and teaching techniques that it was made before. Beside the teacher-researcher conducts acting, the teacher-researcher also observes it and make field notes based on everything happens in the classroom. The teacher-researcher investigated what happens in teaching and learning process in the classroom. The teacher-researcher took note about the condition and the situation during learning process. The teacher-researcher gave a test before and after in teaching and learning process aiming to know the previous knowledge, to see the young learners' understanding about vocabulary, and to see whether the students could improve their vocabulary.

The last stage is reflecting. In this case, the teacher-researcher gives the test to the young learners to know their understanding and this test relates to vocabulary in the English song. Since, the subject is young learner approximately 3-4 years old, the teacher-researcher reads some question then the learners answer it orally. The teacher-researcher uses bilingual language (Indonesian and English) to conduct the test. It aims to know what is needed to increase during the implementation of using English song. The teacher-researcher can observe whether the acting activity have result or any progress or not in the classroom. The score test is very useful to help the teacher-researcher to make a reflection for what should be improved in the next cycle.

To find the degree of the young learners' achievement in each activity, the score of each young learner is counted individually by using the following formula:

The score $=\underline{\text { Number } \text { of right }}$ answer $\quad X 100$

Number of question

While the average of young learners' score is counted by using the following formula:

The average of young learners' score $=\underline{\text { Total of the score }}$

\section{Number of the young learners} If the result of the showed improvement, it should indicate the implementation of using English song brings some effects on solving problem. Moreover, the score test would be showed the evident of the improvement on test in cycle one and cycle two. 


\section{Findings and Discussions}

The teacher-researcher analysed the observation checklists, interviews and field notes, she describes that the identification problem was done in the preliminary study, namely:

Tunggadewi DWP UGM day-care had no English subject; (2) the young learners did not have English knowledge. All of them lacked of vocabulary mastery. Therefore, based on the problems identification, the teacher-researcher made some plans and actions to improve the young learners' vocabulary in English.

\section{Cycle One}

The teacher-researcher made a plan to apply English songs in order to increase the young learners' vocabulary mastery. One of the songs was based on the theme which was transportation. The title of the song was "Row Row Your Boat". In the planning step, she also prepared lesson plans which were based on the "kurikulum" and "pogram semester" in Tungga Dewi day-care. The young learners introduced and learnt some vocabularies with English songs, but the teacher-researcher focused on five vocabularies (row, boat, stream, sail, and wind) in the lyrics of
"Row Row Row Your Boat" song. The teacher-researcher considered the research subject and the time of teaching-learning. The research subject was the young learners approximately 3 4 years old. They learnt English in the first time in the need analysis.

Besides, the principal gave 30 minutes each day to the teacherresearcher for conducting the research. The young learners could not master all vocabularies in four songs in the 30 minutes. Since it would force them for memorize. They easily got bored and forgot because of their span attention.

Another instruments beside the English songs, the teacher- researcher used test to measure the young learners' understanding. The teacher-researcher gave test to the young learners in order to measure their understanding about the learning. The result of the test in cycle one showed on below.

Based on the table above, it could conclude that the implementation of English songs in cycle 1 could not be regarded as successful because the result of the test was fewer than 75 . Therefore, the teacher-researcher decided to conduct next cycle in order to increase the young learners' vocabulary mastery and the young learners' score. 
Table 4.1 the result of the tests in cycle one

\begin{tabular}{llcc}
\hline No & \multicolumn{1}{c}{ Name } & $\begin{array}{c}\text { Pre-test } \\
\text { Score }\end{array}$ & $\begin{array}{c}\text { Post-test } \\
\text { Score }\end{array}$ \\
\hline 1. & Alan & 0 & 0 \\
2. & Alena & 0 & 40 \\
3. & Anisa & 0 & 0 \\
4. & Dania & 0 & 60 \\
5. & Gita & 0 & 40 \\
6. & Laila & 0 & 60 \\
7. & Kaka & 0 & 60 \\
8. & Khanza & 0 & 60 \\
9. & Mua'fa & 0 & 20 \\
& Total of the score & 0 & 340 \\
& $\quad$ Average & 0 & 37,8 \\
\hline
\end{tabular}

\section{Cycle Two}

The problems which arose in the cycle one had been analysed. They were (1) the young learners were confusing during learning process in the class; (2) the young learners were not familiar with the English vocabularies and songs; (3) the young learners got boredom while singing "Row Row Your Boat" song in the class; and (4) the young learner did not focus on the learning process. Therefore, the teacherresearcher tried to increase and solve the problems in cycle two.

In cycle two the teacherresearcher had plans that the teacherresearcher tried to drill their vocabularies using English song ("Circle" song and "Row Row Row Your Boat" song). It added in the core of teaching before starting first activity and second activity in lesson plan in order to make better understanding and make them familiar with English vocabularies; the teacher-researcher should give the instructions clearly than it should be clearer than the instruction in cycle one; and the teacher-researcher made the class more energizing and involve physical movement than cycle one. For a song entitled "Row Row Your Boat, the teacher-researcher tried to add some physical movement to the young learners in order to decrease the young learners' boredom.

After implementing the English songs in the class, the teacher-researcher gave the tests. The teacher-researcher shown the result of pre-test and post-test in cycle 2 ; it could show to know the 
increasing between the pre-test and posttest score in cycle two and answered the aiming on this research; and it could be seen as on below:

Table 4.2 the result of the tests in cycle two

\begin{tabular}{llcc}
\hline No & Name & $\begin{array}{c}\text { Pre-test } \\
\text { Score }\end{array}$ & $\begin{array}{c}\text { Post-test } \\
\text { Score }\end{array}$ \\
\hline 1. & Alan & 60 & 60 \\
2. & Alena & 60 & 100 \\
3. & Anisa & 40 & 60 \\
4. & Dania & 40 & 80 \\
5. & Gita & 40 & 40 \\
6. & Laila & 60 & 100 \\
7. & Kaka & 40 & 100 \\
8. & Khanza & 0 & 100 \\
9. & Mua'fa & 60 & 60 \\
& Total of the score & 400 & 700 \\
& $\quad$ Average & 44,44 & 77,78 \\
\hline
\end{tabular}

From the table 4.2 , it could explained that between pre-test and posttest, there was increasing because in the pre-test score was 44,44 and the posttest score was 77,78. According to Herawati Susilo, et. al., (2009:55), the action research was called be successful if the average amount 75 score while, in cycle two, the post-test got 77,78, because of the getting score more than 75; the teacher-researcher stopped to conduct the research using English songs in the young learners class.

\section{Conclusion and Recommendation}

Songs contributes many things to language teaching in young learners' class. They might be used for relaxing, playing games, changing the activity, connecting with new topic and introducing the vocabularies. Furthermore, introducing songs in the class can increase the young learners' interest, motivation, and participation in language learning.

This research used English songs to increase young learners' vocabularies mastery in the class. Based on the research findings and data analysis, there were two conclusions proposed here. Firstly, English songs could increase the young learners' vocabularies mastery. In cycle one, the score total of pre-test was zero (0) and the score of the post-test was 340. It 
indicated that the young learners' score increased from score zero (0) to 340 and the average increased from score (0) to 37,8. Besides, in cycle two, the score total of pre-test was 400 and the score post-test was 700. This score got improvement amount 300 from score 400 to 700 . The average of the young learners' score in the pre-test was 44,44 and the post-test was 77,78 , so it occurred increasing amount 33,34. In other words, from the result in cycle one and cycle two, it shown that there was significant increasing. The average score of young learners' post-test in cycle two was 77,78 and this average score higher than 75. According to Herawati Susilo, et al., (2009: 55), the teacher-researcher who got score 75 from the young learners' average score can be said success in conducting the research. Because of the successful achievement, the teacher-researcher decided to stop the cycle of this research.

\section{Recommendation}

Based on the data analysis conclusion above, this research has recommendations for the teachers, the parents, and the futures researchers. The teacher can use English songs to teach and introduce the vocabularies for young learners. The using of songs was flexible and implemented the techniques in appropriate way. This technique can be combined with games or using pictures or involving body movements. The parents take big contribution in young learners' development and education. Therefore, this research suggests that the parents can use English songs in practising and increasing their children vocabularies at home. Based on the result of this research, using songs can increase the young learners' vocabularies mastery and young learners' self-confidence. There is possibility that the further researcher used the result of this research as a reference for conducting the research in same topic.

\section{References}

Brewster, J., Ellis, G., and Girard, D. 2002. The Primary English Teacher's Guide. Harlow: Pearson Education Limited.

Brown, H.D. 2001. Teaching by Principles an Interactive Approach to Language Pedagogy. New York: San Francisco State University.

Herawati, S., et al. 2009. Penelitian Tindakan Kelas. Malang: Bayumedia Publising.

Prandika, W. 2013. The Implementation of Flash Cards to Improve Irregular Verbs Mastery among the Eight Grade Students of SMPN3 Klaten. Unpublished thesis.Yogyakarta: Sanata Dharma University. 
Rosari, M. K. H. 2005. Designing a Set of Instructional Materials Using Songs for Maria Kindergarten Students to Introduce New English Vocabulary. Unpublished thesis. Yogyakarta: Sanata Dharma University.

$\begin{array}{ccc}\text { Tjokrosuprihatono, } & \text { D. } & 2010 . \\ \text { Mengenalkan Bahasa } & \text { Asing, } \\ \text { Mengapa Tidak?. Tabloid } & \text { Nova. } \\ \text { Available } & & \text { from: }\end{array}$

http://www.tabloidnova.com/Nova/K

eluarga/Anak/Mengenalkan-Bahasa-

Asing-Mengapa-Tidak/.

(Accessed:13rd March 2015).

Undang Undang No. 20 Tahun 2003 